\title{
SISTEM INFORMASI PERSEDIAAN BARANG BERBASIS DEKSTOP PADA PT. ULTRA SAKTI
}

\author{
Eni Pudjiarti ${ }^{1}$, Eka Puspitasari ${ }^{2}$, Aprillia Ananda Septyawati ${ }^{3}$ \\ ${ }^{1}$ Program Studi Teknik Informatika, Sekolah Tinggi Manajemen Informatika dan Komputer \\ Nusa Mandiri, Jakarta \\ ${ }^{2}$ Program Studi Teknologi Komputer, Universitas Bina Sarana Informatika, Jakarta \\ ${ }^{3}$ Program Studi Sistem Informasi Akuntansi, Universitas Bina Sarana Informatika, Jakarta \\ e-mail: ${ }^{1}$ eni.epr@ nusamandiri.ac.id, ${ }^{2}$ eka.eps@bsi.ac.id, \\ ${ }^{3}$ april.tya92@gmail.com
}

\begin{abstract}
Abstrak
Berdasarkan penelitian yang telah dilakukan pada PT. Ultra Sakti diperoleh bahwa sistem yang diterapkan di perusahaan tersebut belum menggunakan sistem yang baik dalam proses kegiatannya sehari-hari. Sedangkan sistem persediaan barang merupakan hal yang sangat penting untuk melakukan kegiatan kerja, karena dari sistem persediaan barang tersebut bisa dijadikan tolak ukur kinerja atau cash flow perusahaan. Diketahui sistem persediaan barang belum terkomputerisasi dengan baik. Masih menggunakan media kertas untuk mencatat setiap transaksi yang terjadi pada perusahaan tersebut. Akibatnya sering terjadi kesalahan dalam pengerjaan laporan dikarenakan hilang nya data persediaan dan bukti transaksi. Berdasarkan dari permasalahan yang terjadi, maka dibutuhkannya sebuah rancangan sistem yang terkomputerisasi dengan baik agar dapat mengurangi kesalahan yang fatal pada proses pembuatan laporan persediaan barang. Berdasarkan permasalahan yang terjadi, penulis mencoba merancang sebuah aplikasi guna membantu aktivitas kegiatan pengelolaan data persediaan barang di perusahaan tersebut dengan menggunakan Bahasa Pemrograman VB 6.0. Adapun metode pengembangan aplikasi dilakukan dengan menggunakan metode Waterfall.
\end{abstract}

Kata $\mathbf{k u n c i}$ - sistem persediaan barang, visual basic 6.0, metode Waterfall

\begin{abstract}
Based on research that has been done at PT. Ultra Sakti obtained that the system applied in the company has not used a good system in the process of activities daily. While the goods inventory system is very important to do work activities, because of the inventory system can be used as a benchmark performance or cash flow company. It is known that the goods inventory system has not been computerized properly. Still, use paper media to record every transaction that happens to the company. As a result, there is often an error in report execution due to loss of inventory data and transaction evidence. Based on the problems that occur, the needs of a computerized system design well to reduce the fatal errors in the process of creating inventory reports. Based on the problem, the author tried to design an application to help the activities of data management activities in the company using VB programming language 6.0. The method of application development is done using the Waterfall method.
\end{abstract}

Keywords - Inventory System, visual basic 6.0, Waterfall Method 
Jusikom : Jurnal Sistem Komputer Musirawas Vol 04 No 02 Desember 2019
Eni Pudjiarti, Eka Puspitasar,

Aprilia Ananda Septyawati

\section{PENDAHULUAN}

PT. Ultra Sakti merupakan perusahaan yang bergerak di bidang farmasi. Saat ini sistem Persediaan Barang pada PT. Ultra Sakti masih menggunakan metode manual dalam pengelolaan data. Dengan metode yang masih manual tersebut banyak sekali ditemukan permasalahan. Adapun permasalahan yang sering terjadi yaitu adanya kesalahan dalam pencatatan dan akan berpengaruh kesemua proses bahkan dapat berpengaruh ke pendapatan perusahaan. Oleh karena itu sistem manajemen persediaan harus dibuat sebaik mungkin sehingga tidak menghambat kegiatan kerja. Pencatatan barang keluar dan masuk harus benar-benar akurat, sehingga pemakai data bisa menggunakan data dengan sebagaimana mestinya[1].

\section{TINJAUAN PUSTAKA}

\subsection{Sistem}

Sistem merupakan suatu jaringan kerja dari prosedur yang saling berhubungan, kemudian berkumpul bersama untuk melakukan suatu kegiatan demi mencapai sasaran tertentu[2] karena pada dasarnya sistem adalah sekelompok unsur yang hubungannya sangat erat dengan yang lainnya, dan mempunyai fungsi untuk mencapai tujuan tertentu[3].

Konsep sebuah sistem merupakan konsep yang sederhana namun telah digunakan di berbagai bidang untuk mendefinisikan sebuah sistem. Dari konsep tersebut terdapat klasifikasi sistem yang diklasifikasikan dari berbagai sudut pandang[4]. Adapun Gambaran sistem secara sederhana dapat digambarkan sebagai berikut : INPUT $\square$ PROCESS OUTPUT “. Dari gambaran tersebut pada umumnya sistem dikenal sebagai suatu proses untuk mengubah input menjadi output[5] dan sistem sendiri mempunyai karakteristik atau sifat-sifat tertentu[4].

\subsection{Informasi}

Informasi biasanya digunakan dalam setiap proses pengambilan keputusan. Dimana data yang didapat kemudian dikelola dan diproses dengan tujuan bisa memberikan jawaban yang tepat[7].

Dalam mengelola sebuah informasi dibutuhkan sekumpulan data yang saling berkaitan, data tersebut dikumpulkan setelah itu diproses, disimpan, dan didistribusikan kemudian digunakan sebagai pendukung pengambilan keputusan serta pengawasan didalam sebuah organisasi[8].

1. Komponen Masukan (Input Block)

2. Komponen Model (Model Block)

3. Komponen Keluaran (Output Block)

4. Komponen Teknologi (Technology Block)

5. Blok Basis Data (Database Block)

6. Komponen Kendali (Control Block)

7. Komponen Hardware

8. Komponen Software

Dari serangkaian komponen informasi yang ada, maka informasi merupakan data yang telah diolah yang siap digunakan[5].

\subsection{Persediaan}

Persediaan merupakan barang yang disimpan untuk digunakan nanti dan dijual pada masa tertentu dimasa yang akan datang, tentunya tergantung pada permintaan yang ada. Persediaan terdiri dari persediaan barang baku, persediaan barang setengah proses produksi, sedangkan untuk persediaan barang jadi disimpan sebelum dijual atau dipasarkan[9]. Pada dasarnya tujuan dari persediaan adalah untuk memudahkan dan melancarkan proses produksi pada perusahaan dalam memenuhi kebutuhan konsumennya. Dalam hal pemenuhan dibutuhkan waktu untuk menyelesaikan produksi dan memindahkan produk dari suatu proses ke proses yang lain[9]. 
Jusikom : Jurnal Sistem Komputer Musirawas Vol 04 No 02 Desember 2019
Eni Pudjiarti, Eka Puspitasar, Aprilia Ananda Septyawati
Persediaan merupakan asset atau aktiva lancar yang dimiliki oleh perusahaan yang biasanya melakukan kegiatan bisnis dengan menjual barang dagangan atau barang hasil produksi[10]. Adapun metode pencatatan persediaan dibagi menjadi dua yaitu :

\section{Metode Phisik (Periodik)}

Mengenai metode persediaan secara periodik sebagai berikut menurut sistem periodik (periodic inventory system), kuantitas persediaan ditangan ditentukan, seperti yang tersirat oleh namanya, secara periodik. Semua pembelian persediaan selama periode akuntansi dicatat dengan mendebet akun pembelian. Total akun pembelian pada akhir periode akuntansi ditambahkan ke biaya persediaan di tangan pada awal periode untuk menentukan total biaya yang tersedia untuk dijual selama periode berjalan. Kemudian total biaya barang yang tersedia untuk dijual dikurangi dengan persediaan akhir untuk menentukan Harga Pokok Penjualan. Harga pokok penjualan adalah jumlah residu yang tergantung pada hasil perhitungan persediaan akhir secara fisik. Perhitungan fisik persediaan (physical inventory count) yang diharuskan oleh sistem persediaan periodik dilakukan sekali satu tahun pada setiap akhir tahun[11].

2. Metode Perpectual (buku)

Catatan yang berkelanjutan menyangkut perubahan persediaan dicerminkan dalam akun persediaan. Yaitu, semua pembelian dan penjualan (pengeluaran) barang dicatat langsung ke akun persediaan pada saat terjadi[11]. Karakteristik akuntansi dari sistem perpectual adalah:

a. Pembelian barang dagang untuk dijual atau pembelian bahan baku untuk produksi didebet ke persediaan dan bukan ke pembelian. b. Biaya transportasi masuk, retur pembelian dan pengurangan harga, serta diskon pembelian dicatat dalam persediaan bukan dalam akun terpisah.

c. Harga pokok penjualan diakui untuk setiap penjualan dengan mendebet akun Harga Pokok Penjualan, dan mengkredit Persediaan.

d. Persediaan merupakan akun pengendali yang didukung oleh buku besar pembantu yang berisi catatan persediaan individual. Buku besar pembantu memperlihatkan kuantitas dan biaya dari setiap jenis persediaan.

Persediaan dapat diartikan sebagai sumber daya yang belum terpakai dan yang akan digunakan di masa yang akan datang melalui suatu proses lebih lanjut. Kegiatan yang dilalui untuk melakukan suatu persediaan yaitu kegiatan produksi pada sistem manufaktur, kegiatan pemasaran pada sistem distribusi ataupun kegiatan konsumsi pada setiap konsumen[12].

\subsection{Program}

Kata, ekspresi, pernyataan atau kombinasinya yang disusun dan dirangkai menjadi satu kesatuan prosedur yang berupa urutan langkah digunakan untuk menyelesaikan masalah yang diimplementasikan dengan menggunakan bahasa pemrograman sehingga dapat di eksekusi oleh computer[12].

\subsection{Visual Basic 6.0}

Sebuah pemrograman yang menawarkan Intergrated Development Environment (IDE) visual untuk membuat program perangkat lunak berbasis operasi Microsoft Windows menggunakan model pemrograman (COM)[13]. 


\section{METODOLOGI PENELITIAN}

\subsection{Metode Pengembangan Sistem}

Dalam membangun sebuah perangkat lunak dibutuhkan sebuah cara atau metodologi sebagai panduan untuk mendapatkan perangkat lunak yang diharapkan, oleh karena itu digunakan sebuah metode pengembangan sistem dan metode pengumpulan data untuk menunjang kebutuhan perancangan sistem yang akan dibangun. Metode pengembangan sistem yang digunakan dalam perancangan sistem ini adalah metode Waterfall[14]. Berikut adalah tahapan-tahapan dalam metode Waterfall:

\section{Rekayasa Sistem}

Permodelan ini diawali dengan mencari kebutuhan dari keseluruhan sistem yang akan diaplikasikan ke dalam bentuk software. Hal ini sangat penting, mengingat software harus dapat berinteraksi dengan elemen-elemen yang lain seperti hardware, database, dsb. Tahap ini disebut dengan Project Definition.

2. Perangkat Lunak Syarat Analisis (Software Requirements Analysis).

Analisis merupakan tahap awal dimana dilakukan proses pengumpulan data, identifikasi masalah, dan analisis kebutuhan sistem hingga aktivitas pendefinisian sistem. Tahap ini bertujuan untuk menentukan solusi yang didapat dari hasil analisa.

3. Perancangan (Design)

Pada tahap ini sistem yang telah dianalisis dan dirancang mulai diterjemahkan kedalam bahasa mesin melalui bahasa pemrograman. Terdiri dari dua proses yaitu pembuatan kode program dan pembuatan antarmuka program untuk navigasi sistem.

\section{Pengkodean (coding)}

Pada tahap ini sistem yang telah dianalisis dan dirancang mulai diterjemahkan kedalam bahasa mesin melalui bahasa pemrograman. Terdiri dari dua proses yaitu pembuatan kode program dan pembuatan antarmuka program untuk navigasi sistem.

\section{Uji Coba (Testing)}

Selanjutnya program harus diuji coba dimana difokuskan terhadap tiga aktivitas yakni logika internal perangkat lunak, pemastian bahwa semua perintah yang ada telah dicoba, dan fungsi eksternal untuk memastikan bahwa dengan masukan tertentu suatu fungsi akan menghasilkan keluaran sesuai dengan yang dikehendaki.

\section{Pemeliharaan (Maintenance)}

Pada tahap pemeliharaan ini ada beberapa hal yang harus diperhatikan, antara lain operator (user) harus bisa menjalankan sistem dengan benar. Jika terjadi kesalahan pada sistem maka seorang maintenance harus bisa memperbaiki kesalahan baik pada sistem ataupun pada jaringan yang terhubung. Maintenance juga harus melakukan automatic update pada anti virus agar komputer tidak terserang virus yang dapat menyebabkan lambatnya penggunaan sistem.

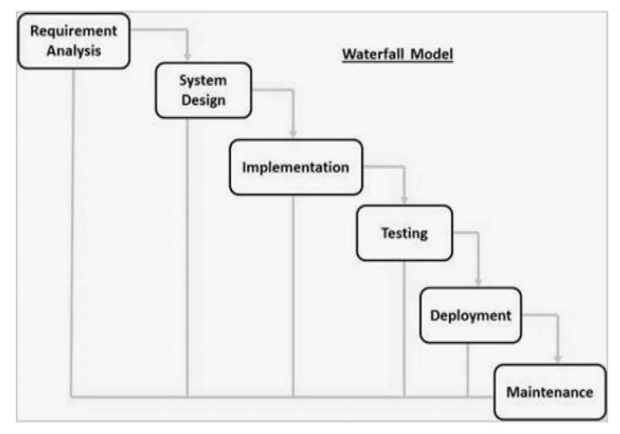

Gambar 1. Ilustrasi Model Waterfall

\subsection{UML (Unified Modeling Language)}

Bahasa pemodelan untuk sistem atau perangkat lunak yang berparadigma (berorientasi objek). Pemodelan sesungguhnya digunakan untuk penyederhanaan permasalahan permasalahan yang kompleks sedemikian 
Jusikom : Jurnal Sistem Komputer Musirawas Vol 04 No 02 Desember 2019
Eni Pudjiarti, Eka Puspitasar, Aprilia Ananda Septyawati rupa sehingga lebih mudah dipelajari dan dipahami[15]. Bahasa pemodelan UML digunakan untuk merancang, mendokumentasikan sebuah sistem perangkat lunak.

\subsubsection{Use Case Diagram}

Permodelan untuk kelakuan (behaviour) sistem informasi yang akan dibuat. Use case mendeskripsikan sebuah interaksi antara satu atau lebih aktor dengan sistem informasi yang akan dibuat. Use case digunakan untuk mengetahui fungsi apa saja yang ada di dalam sebuah sistem informasi dan siapa saja yang berhak menggunakan fungsi-fungsi itu[16].

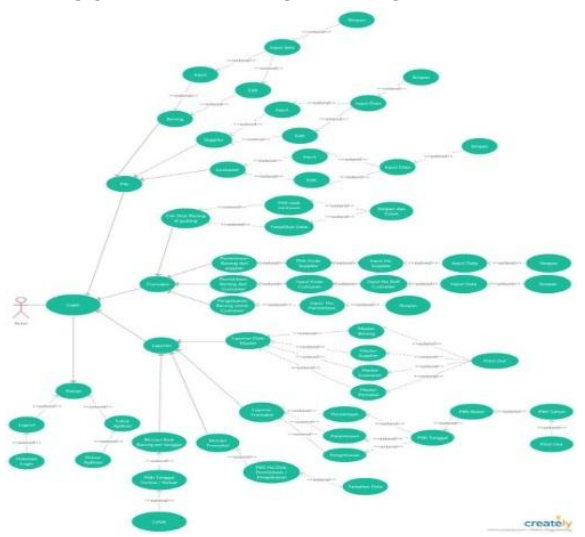

Gambar 2. Use Case Diagram

\subsubsection{Activity Diagram}

Menggambarkan workflow (aliran kerja) atau aktivitas dari sebuah sistem atau proses atau menu yang ada pada perangkat lunak. Activity Diagram menggambarkan aktivitas sistem bukan menggambarkan sesuatu yang dapat dilakukan oleh sistem, bukan apa yang dilakukan oleh aktor[16].

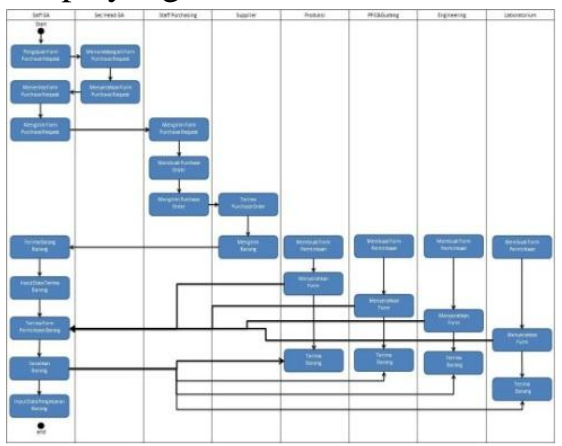

Gambar 3. Activity Diagram

\subsubsection{Class Diagram}

Menggambarkan struktur sistem dari segi pendefinisian class-class yang akan dibuat dalam membangun sistem. Class memiliki apa yang disebut atribut dan method[16]. Berikut penjelasan atribut dan method, yaitu :

1. Atribut merupakan varaibel-variabel yang dimiliki oleh suatu class.

2. Operasi atau method adalah fungsifungsi yang dimiliki oleh suatu class. 3.

\subsubsection{Sequence Diagram}

Menggambarkan kelakuan objek pada use case dengan mendeskripsikan waktu hidup objek dengan message yang dikirimkan dan diterima antar objek. Oleh karena itu untuk menggambarkan diagram sequence maka harus diketahui objek-objek yang terlibat dalam sebuah use case beserta metode-metode yang dimiliki oleh class yang diinstansikan menjadi objek. Untuk membuat diagram sequence dibutuhkan skenario yang ada pada use case[16].

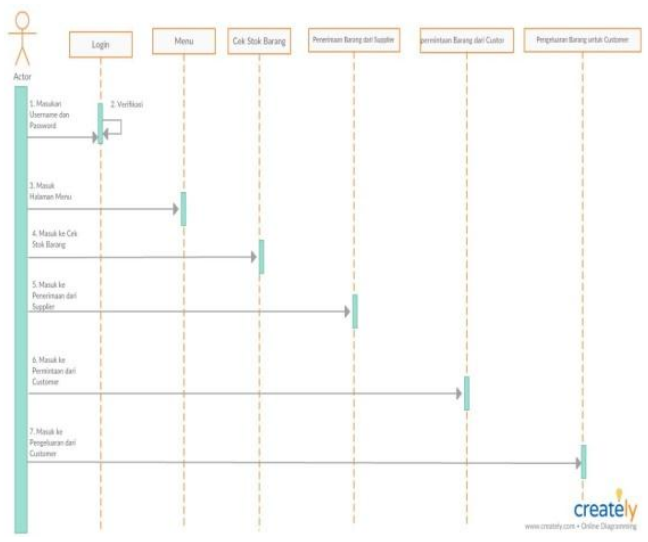

Gambar 4. Sequence Diagram

\section{HASIL DAN PEMBAHASAN}

4.1 Analisis Kebutuhan User

a. User dapat mengolah data barang

b. User dapat mengolah data supplier

c. User dapat mengolah data divisi

d. User dapat melakukan pemesanan barang 

e. User
dapat
melakukan penerimaan barang dari supplier
f. User dapat melakukan permintaan barang
g. User dapat melakukan pengeluaran barang
h. User dapat membuat laporan- laporan

\subsection{Entity Relationship Diagram (ERD)}

Suatu model jaringan yang menggunakan susunan data yang disimpan dalam sistem secara abstrak[4]. Gambaran rancangan ERD dari sistem informasi persediaan barang pada PT. Ultra Sakti adalah sebagai berikut :

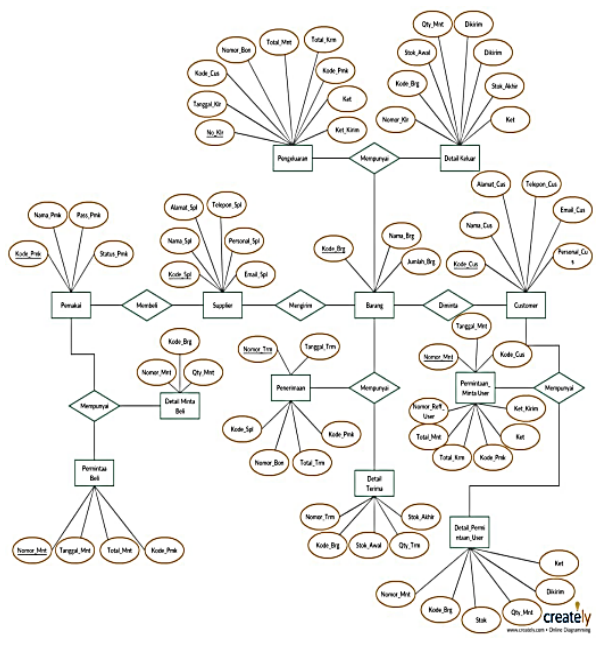

Gambar 5. Entity Relationship Diagram (ERD)

\subsection{Logical Record Structure (LRS)}

Digambarkan dengan kotak persegi panjang dan dengan nama yang unik. File record pada LRS ditempatkan dalam kotak[4]. Rancangan dari tabel-tabel yang diusulkan adalah sebagai berikut :

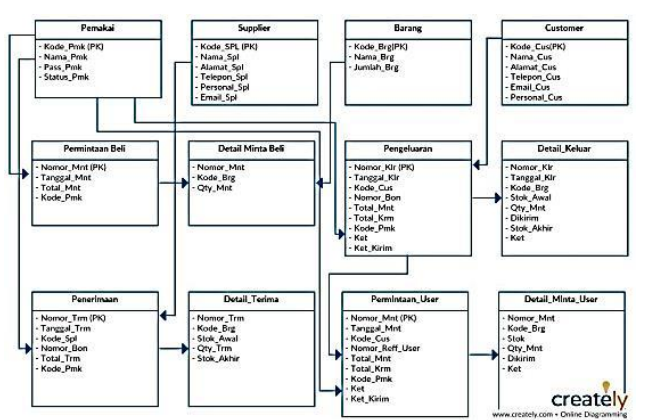

Gambar 6. Logical Record Structure (LRS)

\subsection{Struktur Tampilan}

\section{Halaman Login}

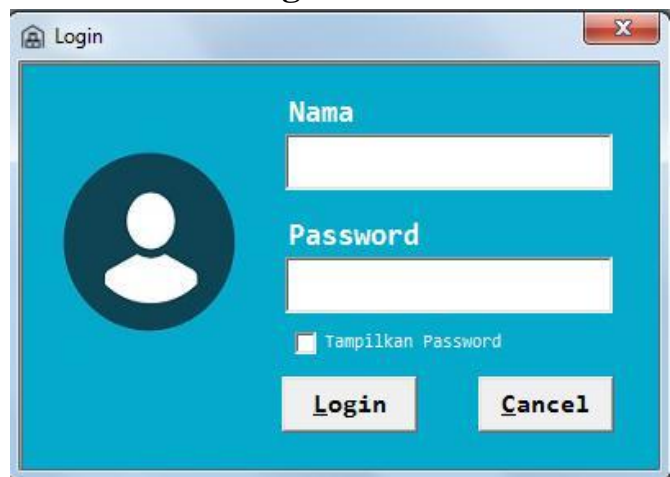

Gambar 6. Form Halaman Login

\section{Halaman Menu Utama}

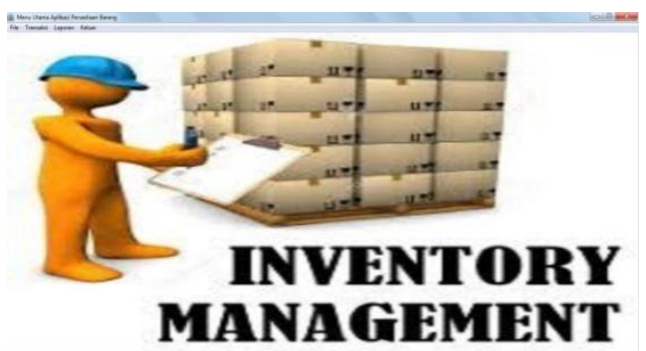

Gambar 7. Form Halaman Menu Utama

\section{Halaman Data Barang}

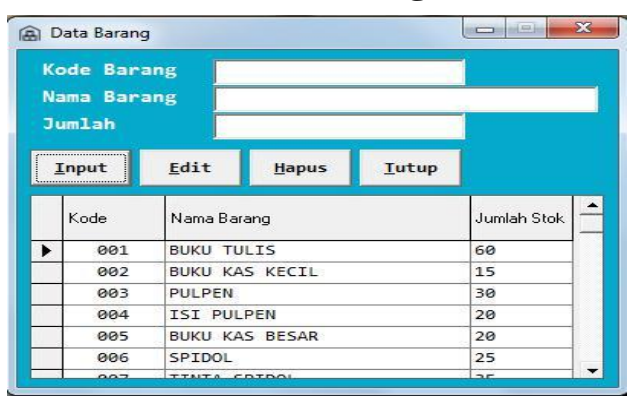

Gambar 8. Form Halaman Data Barang 
Jusikom : Jurnal Sistem Komputer Musirawas Vol 04 No 02 Desember 2019
Eni Pudjiarti, Eka Puspitasar, Aprilia Ananda Septyawati

\section{Halaman Data Supplier}

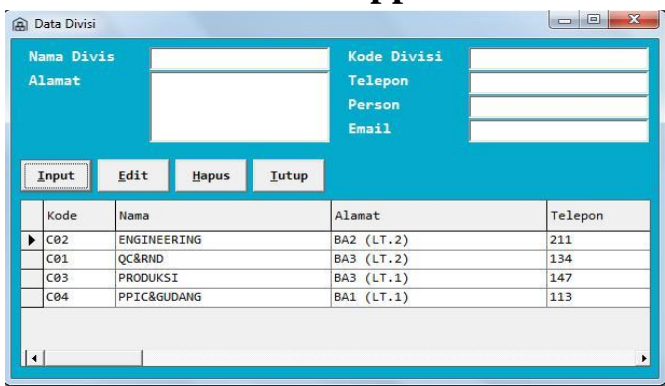

Gambar 9. Form Halaman Data Supplier

\section{Halaman Data Divisi}

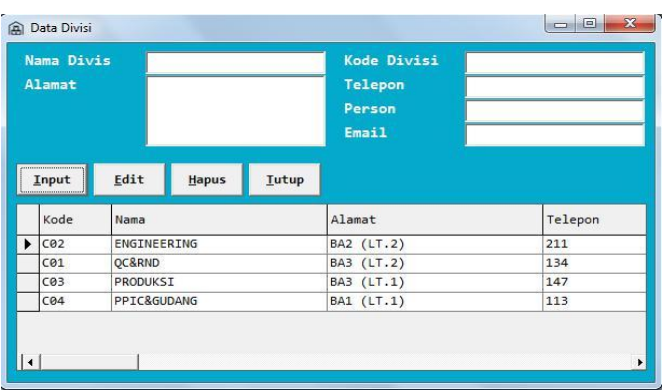

Gambar 11. Form Halaman Data Divis

\section{Halaman Pemesanan Barang}

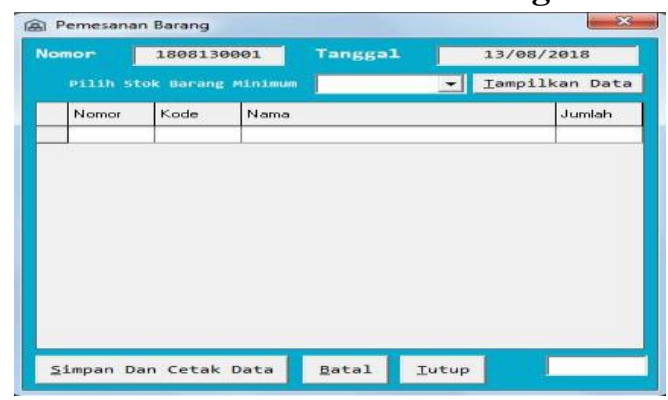

Gambar 10. Form Halaman Pemesanan

Barang

\section{Halaman Penerimaan Barang}

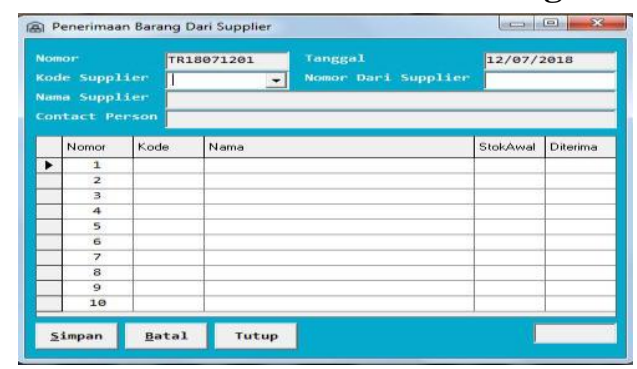

Gambar 11. Form Halaman Penerimaan Barang

\section{Halaman Permintaan Barang}

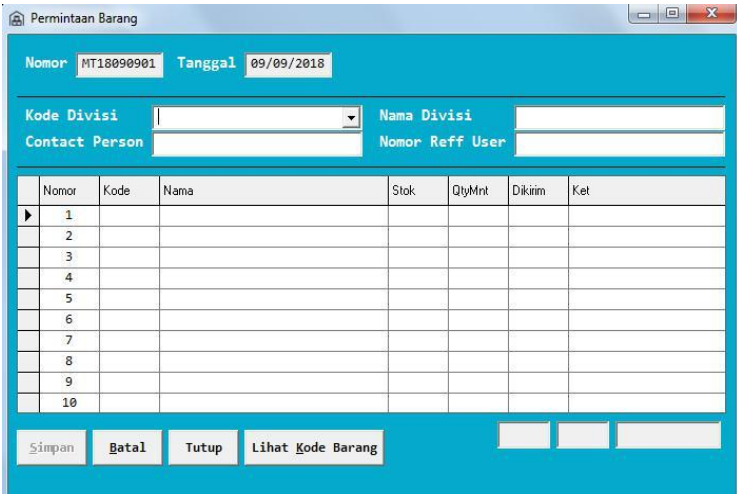

Gambar 12. Form Halaman Permintaan Barang

\section{Halaman Pengeluaran Barang}

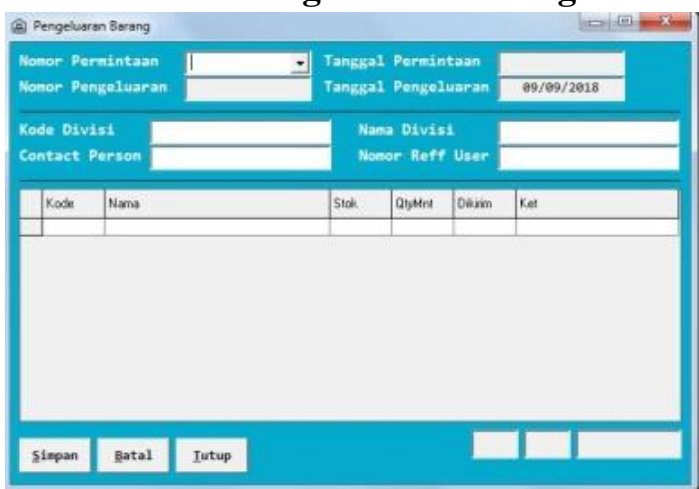

Gambar 13. Form Halaman

Pengeluaran Barang

\section{Halaman Laporan Data Barang}

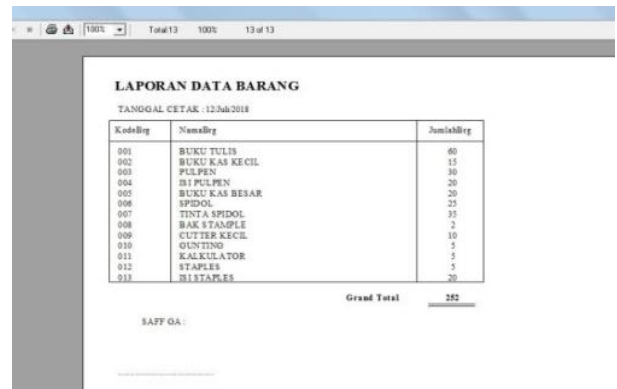

Gambar 14. Form Halaman Laporan Data Barang 


\section{Halaman Laporan Data Supplier}

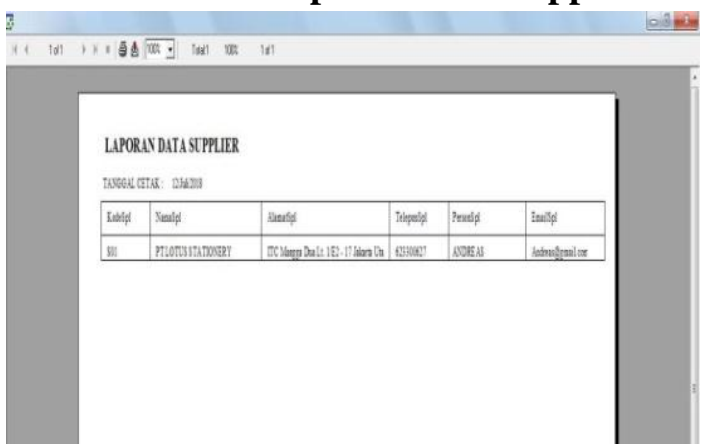

Gambar 15. Form Halaman Laporan Data Supplier

\section{Halaman Laporan Data Divisi}

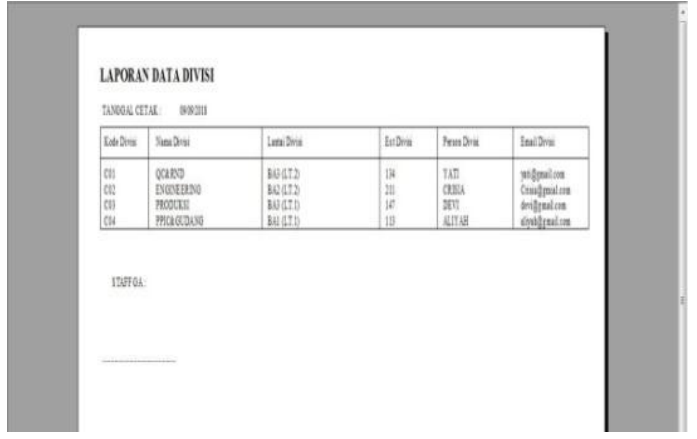

Gambar 16. Form Halaman Laporan Data Divisi

\section{Halaman Laporan Transaksi Penerimaan}

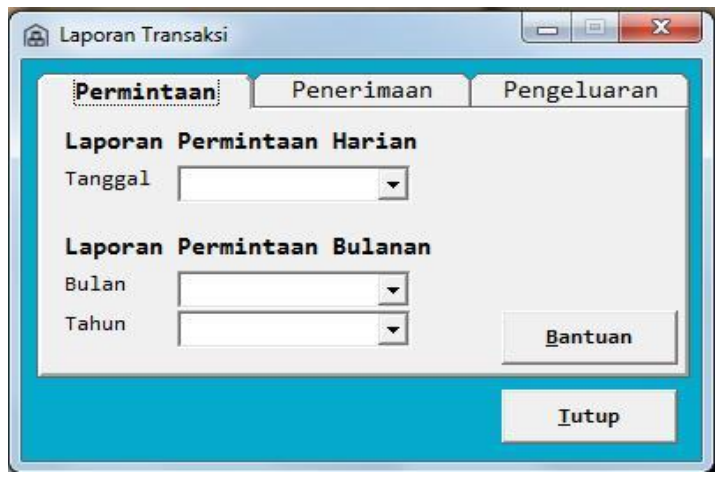

Gambar 17. Form Halaman Laporan Transaksi Penerimaan

\section{Halaman Rincian Transaksi Permintaan dan Penerimaan}

\begin{tabular}{|c|c|c|c|c|c|c|c|c|}
\hline (⿵⺆⿱土口⿰亻⿱丶⿻工二口 Rincian TRansaksi & & & & & & & & \begin{tabular}{|l|l|}
0 & 0 \\
\end{tabular} \\
\hline \multicolumn{9}{|l|}{ Pemintaan } \\
\hline 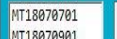 & Kods & Namis & & Stok & Elywint & Dikirin & Ket & \\
\hline NT180712201 & & & & & & & & \\
\hline \multirow{3}{*}{\multicolumn{9}{|c|}{$\begin{array}{l}\text { Pengeluaran } \\
\begin{array}{l}\text { KLL8670701 } \\
\text { KL18870901 } \\
\text { KLL8071201 }\end{array}\end{array}$}} \\
\hline & & & & & & & & \\
\hline & & & & & & & & \\
\hline Tanggal & & & Contact Person & & & & & \\
\hline Nana Customer & & & Nomor Nota & & & & & \\
\hline
\end{tabular}

Gambar 18. Form Halaman Rincian Transaksi

\section{KESIMPULAN}

Berdasarkan pembahasan mengenai pembuatan sistem persediaan barang yang sebelumnya masih menggunakan sistem secara manual, dimana setiap prosesnya memerlukan waktu yang lama pada saat pencatatan, proses, serta mungkin menghasilkan data yang tidak maksimal. Hal ini akan menyebabkan proses persediaan yang tidak akurat.

Pengolahan data yang dibuat secara terkomputerisasi dapat meminimalisir kesalahan human error pada saat sistem masih dilakukan secara manual. Sehingga proses pengadaan, penerimaan dan pengeluaran bisa berjalan dengan baik dan benar.

\section{SARAN}

Berdasarkan kesimpulan dari pembahasan dan penjelasan di atas, agar dapat meningkatkan kualitas kinerja lebih optimal, berikut saran-saran yang dapat diberikan :

1. Dalam pengoperasian komputer, hendaknya karyawan dilengkapi dengan pengetahuan mengenai komputer agar tidak terjadi kesalahan dan kerusakan data pada komputer itu sendiri.

2. Diperlukan adanya pemeliharaan dan perawatan secara rutin terhadap 
Jusikom : Jurnal Sistem Komputer Musirawas Vol 04 No 02 Desember 2019
Eni Pudjiarti, Eka Puspitasar, Aprilia Ananda Septyawati perangkat keras maupun perangkat lunak demi kelancaran dalam proses pengolahan data alat tulis kantor.

3. Diperlukannya ketelitian terhadap pekerja, sehingga bisa menghasilkan pekerjaan yang maksimal.

\section{DAFTAR PUSTAKA}

[1] R. Rubhyanti and R. Lestianawati, "SISTEM INFORMASI PENGELOLAAN PERSEDIAAN BAHAN BAKU BERBASIS CLIENT SERVER PADA CV. ALINEA JAVA SEMARANG," 2018.

[2] J. Hutahaean, Konsep Sistem Informasi. Yogyakarta: Deepublish, 2014.

[3] Mulyadi, Sistem Akuntansi, Edisi 4. Jakarta: Salemba Empat, 2016.

[4] A.-B. Bin Ladjamudin, Analisis dan Desain Sistem Informasi. Yogyakarta: Graha Ilmu, 2013.

[5] A. mujilan, Sistem Informasi Akuntansi, teori dan wawasan di dunia elektronis. Madiun, 2015.

[6] D. H. Rusdiana M and M. Irfan S.M, Sistem Informasi Manajemen. Bandung: Pustaka Setia, 2014.

[7] R. Marshall B and Steinbart, Sistem Informasi Akuntansi. Jakarta: Salemba Empat, 2015.

[8] L. Kenneth C and L. Jane P, Sistem Informasi Manajemen:Mengelola Perusahaan Digital, 13th ed. Jakarta: Salemba Empat, 2014.

[9] K. R. Karongkong, V. Ilat, and V. Z. Tirayoh, "Penerapan Akuntansi Persediaan Barang Dagang Pada UD. Muda-Mudi ToliToli," J. Ris. Akunt. Going Concern, vol. 2, pp. 46-56, 2018.

[10] M. E. Wijaya, "PERANCANGAN SISTEM INFORMASI PERSEDIAAN BARANG PADA PT. CIPTA PRIMA

\section{SUPERMARKET BERBASIS \\ DESKTOP," SEKOLAH TINGGI MANAJEMEN INFORMATIKA DAN KOMPUTER (STMIK) GICI BATAM, 2017.}

[11] Kieso, Weygandt, and Warfield, Akuntansi Intermediate, Kedua bela. Jakarta, 2011.

[12] W. Nugraha, M. Syarif, and W. S. Dharmawan, "PENERAPAN

METODE SDLC WATERFALL DALAM SISTEM INFORMASI INVENTORY BARANG BERBASIS DESKTOP," STMIK MUSIWARAS Lubuklinggau, vol. 3, pp. 22-28, 2018.

[13] Stefano, Cara Membangun Sistem Informasi Mengunakan VB.Net dan Komponen Dxperience. Yogyakarta: C.V Andi Offset, 2014.

[14] R. S. Pressman, REKAYASA PERANGKAT LUNAK PENDEKATAN PRAKTISI.

Yogyakarta: Andi, 2015.

[15] E. Wijayanti, "Perancangan Sistem Informasi Absensi Pegawai Pada Kantor Kecamatan Batuceper Tangerang," 2014.

[16] R. A. Sukamto and M. Shalahuddin, REKAYA PERANGKAT LUNAK TERSTRUKTUR DAN BERORIENTASI OBJEK, 2nd ed. Bandung: Informatika, 2014. 